УДК 336.14

DOI: $10.25140 / 2411-5215-2020-4(24)-74-87$

Сергій Козьменко, Світлана Качула

\title{
СОЦІАЛЬНІ ПРОГРАМИ ЯК ІНСТРУМЕНТ БЮДЖЕТНОЇ ПОЛІТИКИ ЛЮДСЬКОГО РОЗВИТКУ ТА ОЦІНКА ЇХ ЕФЕКТИВНОСТІ
}

\author{
Сергей Козьменко, Светлана Качула \\ СОЦИАЛЬНЫЕ ПРОГРАММЫ КАК ИНСТРУМЕНТ \\ БЮДЖЕТНОЙ ПОЛИТИКИ ЧЕЛОВЕЧЕСКОГО РАЗВИТИЯ \\ И ОЦЕНКА ИХ ЭФФЕКТИВНОСТИ
}

Serhiy Kozmenko, Svitlana Kachula

\section{SOCIAL PROGRAMS AS A TOOL OF HUMAN DEVELOPMENT BUDGET POLICY AND THEIR EFFECTIVENESS ASSESSMENT}

У статті розглянуто теоретичні засади сочіальних бюджетних програм як інструменту бюджетної політики забезпечення людського розвитку. Показано, щео останні роки програмно-цільовий метод став невід'ємною складовою бюджетного процесу в Україні. Здійснено загальний аналіз видатків державного бюджету за програмною класифікаиією видатків у розрізі головних розпорядників бюджетних коштів на розвиток освіти, охорони здоров'я, соціального захисту. Більш детально проаналізовано ефективність бюджетних програм, де головним розпорядником виступає Міністерство сочіальної політики України. Узагальнено проблемні аспекти оцінки ефективності реалізації бюджетних програм та окреслено заходи оптимізаиії видатків бюджету відповідно до сучасних потреб суспільства.

Ключові слова: бюджетна політика; сочіальна бюджетна програма; видатки; програмно-цільовий метод; ефективність; освіта; охорона здоров 'я; соціальний захист.

Табл.: 3. Бібл.: 25 .

В статье рассмотрены теоретические основы сочиальных бюджетных программ как инструмента бюджетной политики обеспечения человеческого развития. Показано, что в последние годы программно-иелевой метод стал неотъемлемой составляющей бюджетного процесса в Украине. Осуществлен общий анализ расходов государственного бюджета по программной классификачии расходов в разрезе главных распорядителей бюджетных средств на развитие образования, здравоохранения, сочиальной защиты. Более подробно проанализирована эффективность бюджетных программ, где главным распорядителем выступает Министерство социальной политики Украины. Обобщены проблемные аспекты оченки эффективности реализачии бюджетных программ и намечены меры оптимизации расходов бюджета в соответствии с современными потребностями общества.

Ключевые слова: бюджетная политика; сочиальная бюджетная программа; расходы; программно-иелевой метод; эффективность; образование; здравоохранение; социальная защита.

Табл.: 3. Библ.: 25 .

The article considers the theoretical founations of social budget programs as human development ensuring budget policy tool. It is shown that in recent years the program-target method has become an integral part of the budget process in Ukraine. General analysis of state budget expenditures according to the program classification of expenditures in terms of the main managers of budget funds for the development of education, health care, social protection is done. The authors have analyzed in more detail the effectiveness of budget programs, where the main administrator is the Ministry of Social Policy of Ukraine. The problematic aspects of assessing the effectiveness of budget programs are summarized and measures to optimize budget expenditures in accordance with modern needs of society are outlined.

Keywords: budget policy; social budget program; expenses; program-target method; financial support; efficiency; education; health care; the social protection.

Table: 3. References: 25 .

JEL Classification: E62; H51; H52; H53; H72

Постановка проблеми. Серед результатів руйнівних наслідків глобальної кризи та соціально-економічної нестабільності, спричиненої перебігом та наслідками пандемії COVID-19, - падіння економіки, ділової активності, простої, звуження чи припинення діяльності підприємств, у багатьох випадках - їх банкрутство, отже, зростання безробіття, падіння рівня та якості життя більшості прошарків населення. За таких умов підвищується роль та значення адаптивних заходів бюджетної політики у сфері видатків, зокрема планування видатків бюджету за пріоритетними напрямами підтримки соціуму, інклюзивного розвитку. Найактуальнішим завданням бюджетної політики стає забезпечення достатнього фінансування державних соціальних програм та підвищення ефективності використання бюджетних коштів для досягнення запланованих цілей в умовах бюджетних обмежень.

(C) Козьменко С. М., Качула С. В., 2020 
ФІНАНСОВІ РЕСУРСИ: ПРОБЛЕМИ ФОРМУВАННЯ ТА ВИКОРИСТАННЯ

Аналіз останніх досліджень і публікацій. Проблемі забезпечення соціального вектора цілей сталого розвитку з використанням інструментарію бюджетної політики та необхідності оптимізації і підвищення ефективності видатків державного і місцевих бюджетів бюджету з використанням прогресивних технологій бюджетування, реалізації державних цільових програм, застосування аудиту ефективності, а також оцінювання результатів бюджетних програм, покращення становища в соціальній і бюджетній сфері присвячені праці Ф. Журавки та Н. Овчарової [7], Л. Лисяк [2], В. Савченко [19], О. Тимченко [21], I. Чугунова [22], С. Шкарлета, І. Долозіної, М. Дубини [25] та інших.

Виділення недосліджених частин загальної проблеми. Слід зазначити, що соціальні питання вчені досліджують із різних позицій, однак недостатньо наукових праць щодо оцінки ефективності виконання бюджетних програм соціального спрямування, людського розвитку. Виникнення нових соціальних викликів для суспільства, пов'язаних із погіршенням практично всіх складових людського потенціалу в Україні, зумовлюючи падіння загального рівня та якості життя (погіршення стану здоров'я населення, зниження якості та доступності освітніх та медичних послуг, загострення проблем соціального та інституційного середовища), посилюють необхідність забезпечення ефективності використання такого інструменту бюджетної політики, як бюджетні соціальні програми. Оцінка ефективності реалізації бюджетних програм соціального спрямування з метою досягнення цілей сталого розвитку в Україні залишається на сьогодні важливою та актуальною теоретичною і практичною проблемою.

Мета статті - аналіз бюджетних програм як інструменту політики забезпечення людського розвитку, узагальнення проблемних аспектів оцінки ефективності їх реалізації та окреслення заходів оптимізація видатків бюджету відповідно до сучасних потреб суспільства.

Виклад основного матеріалу. Відповідно до концепції розвитку людського потенціалу людський розвиток залежить від розміру і структури соціальних інвестицій, що передбачає вкладення в освіту, професійну підготовку, перепідготовку, освіту впродовж життя, охорону та зміцнення здоров'я, розвиток здібностей людей, сприяння їхній активній участі в суспільному відтворенні. При цьому необхідно дотримуватися певної рівноваги/балансу соціальних інвестицій із реальними інвестиціями, адже останні необхідні для розвитку соціальної інфраструктури, формування підгрунтя для розвитку соціальної сфери. Важливе значення для людського розвитку має зменшення нерівності в суспільстві, захист соціально вразливих верств/прошарків населення.

Протягом останніх років бюджетна політика України у сфері видатків більшою мірою сконцентрована навколо соціальних процесів. Це закономірно, адже заплановане фінансування соціальних видатків, соціальної інфраструктури суттєво впливає на збереження і розвиток людського капіталу, забезпечуючи соціальний захист певних верств населення, підвищення якості послуг у сфері освіти, науки, охорони здоров'я, культурного та духовного розвитку тощо. Фінансовою теорією і реальною практикою доведено, що ефективна бюджетна політика у сфері видатків $\epsilon$ важливим чинником людського розвитку як каталізатора економічного зростання і його кінцевої мети. Масштабні, дієві, результативні вкладення в людський розвиток можливо здійснити лише на рівні держави. Йдеться про державне фінансове забезпечення соціальної складової цілей сталого розвитку до 2030 року - охорони здоров'я, освіти, соціальних гарантій/захисту тощо та водночас заохочення/стимулювання приватних соціальних інвестицій. Окремими дослідниками доведено - частка бюджетного фінансування менше за 35 \% у загальному обсязі фінансування за рахунок усіх джерел спричинить до зловживань із бюджетними коштами [24]. 
Необгрунтовані/неефективні рішення/зміни бюджетної політики, зокрема щодо обсягів, структури і цільової спрямованості бюджетних видатків поряд із негативною дією екзогенних та ендогенних факторів здатні суттєво погіршити стан соціуму, загальмувати прогресивний розвиток суспільства. I навпаки, стійкість, збалансованість, інклюзивність, контрциклічність та інші характеристики й одночасно цілі бюджетної політики 3 урахуванням бюджетно-податкових можливостей суспільства досяжні за умови фіскальної дисципліни, чіткого дотримання бюджетних правил, мінімізації корупції, розробленої бюджетної стратегії, яка враховує соціальні, економічні, демографічні, екологічні, інвестиційні, інноваційні та інші аспекти.

Інноваційним методом підвищення ефективності бюджетної політики у сфері видатків стало впровадження в бюджетну практику багатьох країн програмно-цільового методу управління із застосуванням аналізу та оцінки ефективності бюджетних асигнувань на всіх стадіях бюджетного процесу. Перехід від управління бюджетними витратами до управління бюджетними результатами передбачає формування нової бюджетної архітектоніки та використання такого інструменту бюджетної політики, як бюджетні програми. Ці програми формуються для концентрації бюджетних коштів на вирішення соціальних, економічних, екологічних пріоритетів у середньостроковій та довгостроковій перспективі та є вагомим інструментом підвищення ефективності бюджетних видатків.

За дослідженням I. Чугунова, бюджетна політика матиме дієвий вплив на суспільний розвиток за умови подальшого розвитку програмно-цільового методу (далі - ПЦМ) у бюджетному процесі, зокрема, «забезпечення прозорості діяльності учасників бюджетного процесу щодо досягнення поставлених цілей та виконання завдань за результатами виконання бюджету, проведення аналізу причин неефективного виконання бюджетних програм; упорядкування системи організації діяльності головних розпорядників бюджетних коштів щодо формування і виконання бюджетних програм; посилення відповідальності головного розпорядника бюджетних коштів за дотримання відповідності бюджетних програм законодавчо визначеній меті його діяльності та за фінансове забезпечення бюджетних програм і результати їх виконання; підвищення якості розробленої бюджетної політики, ефективності розподілу і використання бюджетних коштів» [22, с. 9-10].

Поняття «бюджетна програма» визначається в Бюджетному кодексі України як «сукупність заходів, спрямованих на досягнення єдиної мети, завдань та очікуваного результату, визначення та реалізацію яких здійснює розпорядник бюджетних коштів відповідно до покладених на нього функцій» [1, ст. 2]. Основою та підгрунтям розробки бюджетних програм є прогнозні та програмні документи соціального й економічного розвитку суспільства (стратегічні орієнтири розвитку, плани діяльності на середньостроковий період, програми діяльності уряду). Бюджетні програми є інструментом реалізації бюджетної політики та втіленням програмно-цільового методу планування і використання бюджетних коштів.

Увага до оцінки ефективності реалізації бюджетних програм соціального спрямування, людського розвитку зумовлена такими обгрунтованими теоретичними положеннями: по-перше, такі програми вирішують у межах функцій і повноважень держави пріоритетні, життєво важливі проблеми соціуму, завдання підтримки соціально вразливих верств населення і розвитку людини; по-друге, вони передбачають концентрацію бюджетних коштів на досягнення чітко визначених, запланованих результатів, досягнення соціальних та інших цілей; по-третє, оптимально/раціонально/результативно використовуються обмежені бюджетні кошти, що особливо важливо в умовах кризи; почетверте, підвищується прозорість бюджетного процесу, адже наслідки реалізації програм віддзеркалюються в наданні якісних публічних послуг, прогресивному людському розвитку тощо. 
ФІНАНСОВІ РЕСУРСИ: ПРОБЛЕМИ ФОРМУВАННЯ ТА ВИКОРИСТАННЯ

Підвищення ефективності використання бюджетних коштів - проблема, що $є$ актуальною практично для будь-якої країни світу. В Україні розроблена нормативно-правова база оцінки ефективності бюджетних програм (далі - ОЕБП). Загалом оцінка бюджетної програми - «періодичний грунтовний аналіз процесу реалізації програми за показниками виконання 3 метою визначення іiі ефективності й результативності та прийняття управлінських рішень щодо покращення процесу її подальшого впровадження або в разі необхідності призупинення чи припинення» [9]. У Бюджетному кодексі України (ст. 20) зазначено, що на всіх стадіях бюджетного процесу його учасники мають здійснювати ОЕБП у межах своїх повноважень, що передбачає здійснення заходів з моніторингу, аналізу результативних показників бюджетних програм [1]. Тобто оцінка та моніторинг виконання бюджетних програм є вагомими складовими ПЦМ. Враховуючи, що на сьогодні програмно-цільовий метод у бюджетному процесі в Україні застосовується на рівні як державного, так і місцевих бюджетів, бюджетні програми розробляються на загальнодержавному та регіональному/місцевому рівнях. Сформована система нормативних вимог щодо ОЕБП містить методичні рекомендації, розпорядчі документи тощо. Відповідальність за організацію і контроль ОЕБП несе головний розпорядник бюджетних коштів. Важливим аспектом $\epsilon$ використання результатів ОЕБП на всіх етапах бюджетного процесу для прийняття управлінських рішень щодо підвищення ефективності реалізації програм чи внесення необхідних корегувань, особливо у процесі реалізації середньострокового бюджетного планування.

У бюджетній практиці ОЕБП здійснюється на основі аналізу результативних показників, розрахованих та відображених у відповідних паспортах бюджетних програм, у звітах про їх виконання та іншої інформації (наприклад, результатів моніторингу, контрольних заходів, аудиту, обліку тощо). ОЕБП здійснюється для кожної бюджетної програми окремо. За результатами оцінювання головні розпорядники бюджетних коштів мають виявляти причини відхилень, розробляти заходи щодо підвищення ефективності бюджетних видатків та прийняття відповідних рішень.

Впровадження державних цільових програм відбувається в поєднанні з програмною класифікацією видатків, при цьому бюджетні програми соціального спрямування передбачають вирішення різних проблемних питань/аспектів, що стосуються підвищення рівня та якості життя. Серед них - посилення соціального захисту населення, розвиток освіти, зміцнення системи охорони здоров'я тощо. Розглянемо видатки державного бюджету України у 2019-2020 pр. на реалізацію окремих бюджетних програм соціального спрямування в розрізі Головних розпорядників бюджетних коштів (ГРБК) (табл. 1).

Видатки бюджету для реалізації соціальних програм, які є основою підтримки людського розвитку, здійснюється переважно з місцевих бюджетів. Вони становлять понад $60 \%$ загальних видатків на освіту, близько 80 \% видатків на охорону здоров'я. Із державного бюджету забезпечується фінансування видатків на соціальний захист і соціальне забезпечення населення.

Водночас окремі видатки здійснюються з місцевих бюджетів за принципом наближення до споживачів (державні програми фінансування установ соціальної допомоги, притулків, соціального захисту визначених відповідним законодавством категорій населення - ветеранів війни і праці, сімей з дітьми тощо, фінансування витрат з оплати житлово-комунальних послуг та ін.).

В умовах підвищення самостійності місцевих бюджетів, як результату реформи бюджетної децентралізації, зростає кількість регіональних соціальних програм. Так, у Дніпропетровській області у 2019 році реалізувалося 46 регіональних програм, із них 5 програм мають у назві ознаку «соціальні». До них належать: «Цільова соціальна комплексна програма розвитку фізичної культури і спорту в Дніпропетровській області до 
2021 року», Регіональна цільова соціальна програма «Молодь Дніпропетровщини» на 2012-2021 роки, Програма розвитку сімейної та гендерної політики у Дніпропетровській області на 2012-2021 роки та Регіональна цільова соціальна програма «Освіта Дніпропетровщини до 2021 року» [17].

Таблиця 1

Видатки державного бюджету за окремими програмами ГРБК у 2019-2020 рр., млрд грн

\begin{tabular}{|c|c|c|c|c|c|}
\hline \multirow{2}{*}{$\begin{array}{c}\text { Код бюджетної } \\
\text { класифікації }\end{array}$} & \multirow{2}{*}{$\begin{array}{c}\text { Головний розпорядник бюджетних коштів (ГРБК) } \\
\text { та програми }\end{array}$} & \multicolumn{3}{|c|}{2019} & \multirow{2}{*}{$\begin{array}{l}\mathbf{2 0 2 0} \\
\text { план }\end{array}$} \\
\hline & & план & звіт & $\%$ & \\
\hline 2200000 & Міністерство освіти і науки України & 43,5 & 39,14 & 90,0 & 44,60 \\
\hline 2201160 & $\begin{array}{l}\text { Підготовка кадрів ЗВО та забезпечення діяльності їх баз } \\
\text { практики }\end{array}$ & 19,1 & 19,2 & 100,5 & 16,65 \\
\hline 2210000 & $\begin{array}{l}\text { Міністерство освіти і науки України (загальнодержавні } \\
\text { видатки та кредитування) }\end{array}$ & 73,04 & 73,1 & 100,1 & 83,46 \\
\hline 2211210 & $\begin{array}{l}\text { Освітня субвенція з державного бюджету місцевим бю- } \\
\text { джетам }\end{array}$ & 69,6 & 79,4 & 114,1 & 77,53 \\
\hline 2211230 & $\begin{array}{l}\text { Субвенція з державного бюджету місцевим бюджетам } \\
\text { на забезпечення якісної, сучасної та доступної загальної } \\
\text { середньої освіти «Нова українська школа» }\end{array}$ & 1,22 & 1,02 & 83,6 & 1,06 \\
\hline 2211260 & $\begin{array}{l}\text { Субвенція } 3 \text { державного бюджету місцевим бюджетам } \\
\text { на реалізацію програми «Спроможна школа для кращих } \\
\text { результатів» }\end{array}$ & - & - & - & 3,50 \\
\hline 2211250 & $\begin{array}{l}\text { Субвенція з державного бюджету місцевим бюджетам } \\
\text { на реалізацію заходів, спрямованих на підвищення яко- } \\
\text { сті освіти }\end{array}$ & 1,5 & 1,1 & 73,3 & - \\
\hline 2300000 & Міністерство охорони здоров’я України & 39,35 & 39.3 & 99,9 & 98,18 \\
\hline 2310000 & $\begin{array}{l}\text { Міністерство охорони здоров'я України (загальнодер- } \\
\text { жавні видатки та кредитування) }\end{array}$ & 58,62 & 58,12 & 99,2 & 17,71 \\
\hline 2308000 & Національна служба здоров’я України & 19,26 & 18,57 & 96,4 & 89,10 \\
\hline 2308060 & $\begin{array}{l}\text { Ут.ч.: } \\
\text { Реалізачія програми державних гарантій медичного } \\
\text { обслуговування населення }\end{array}$ & - & - & - & 88,88 \\
\hline 230820 & Надання первинної медичної допомоги населенню & 15,9 & 16,75 & 105,3 & - \\
\hline 2308030 & $\begin{array}{l}\text { Пілотний проєкт із реалізаиії державних гарантій ме- } \\
\text { дичного обслуговування населення за програмою медич- } \\
\text { них гарантій для спеціалізованої медичної допомоги в } \\
\text { Полтавській області }\end{array}$ & 0,97 & 0,965 & 99,5 & - \\
\hline 2308050 & $\begin{array}{l}\text { Пілотний проєкт із реалізації державних гарантій ме- } \\
\text { дичного обслуговування населення за програмою медич- } \\
\text { них гарантій для спеціалізованої медичноїдопомоги }\end{array}$ & 2,00 & - & - & - \\
\hline 2500000 & Міністерство соціальної політики України & 229.0 & 217,5 & 95,0 & 293,4 \\
\hline 2510000 & $\begin{array}{l}\text { Міністерство соціальної політики України (загальноде- } \\
\text { ржавні видатки та кредитування) }\end{array}$ & 24,27 & 24,0 & 98,9 & 0,80 \\
\hline
\end{tabular}

Джерело: складено й розраховано за [3; 4].

Кожна із перелічених соціальних програм реалізується за кошти бюджету в рамках бюджетних програм та залучення інших джерел фінансування.

Узагальнимо результати звітів щодо виконання окремих бюджетних програм, у межах яких реалізуються соціальні програми Дніпропетровської області (табл. 2).

Аналіз звітів про виконання паспортів бюджетних програм загалом і наведених у табл. 1 даних свідчить, що в кожному паспорті наводяться результативні показники (кількісні і якісні) - затрат, продукту, ефективності і якості. Показники ефективності $є$ розрахунковими, методика їх розрахунків здійснюється відповідно до Концепції застосування програмно-цільового методу в бюджетному процесі [14]. Показники ефективності бюджетної програми (далі - ЕБП) визначаються як відношення продукту 
ФІНАНСОВІ РЕСУРСИ: ПРОБЛЕМИ ФОРМУВАННЯ ТА ВИКОРИСТАННЯ

(товарів, робіт, послуг) до витрат ресурсів. Це визначення відповідає загальному підходу до ефективності, згідно з яким ефективність оцінюється як співвідношення результатів і витрачених на їх досягнення ресурсів. Водночас, відповідно до цього критерію, переважна більшість показників ефективності, наведених у звітах бюджетних програм, не відповідають сутності цього поняття.

Таблиця 2

Показники ефективності окремих бюджетних програм (БП) реалізації регіональної иільової сочіальної комплексної програми «Розвиток фізичної культури і спорту в Дніпропетровській області» за 2019 рік

\begin{tabular}{|c|c|c|c|}
\hline Показники ефективності & $\begin{array}{c}\text { Затв. } \\
\text { грн }\end{array}$ & $\begin{array}{c}\text { Факт } \\
\Gamma \mathrm{pH}\end{array}$ & $\begin{array}{l}\text { Зміни } \\
\text { грн * }\end{array}$ \\
\hline \multicolumn{4}{|c|}{$\begin{array}{l}\text { БП: «Проведення навчально-тренувальних зборів і змагань з олімпійських видів спорту» (Мета: Ство- } \\
\text { рення умов для забезпечення популяризаичї̈ та розвитку олімпійських видів спорту на місиевому рівні) }\end{array}$} \\
\hline $\begin{array}{l}\text { Середні витрати на один людинодень (далі - СВОЛД) участі в регіональних } \\
\text { змаганнях з олімпійських видів спорту }\end{array}$ & 135 & 140 & 5 \\
\hline $\begin{array}{l}\text { СВОЛД навчально-тренувальних зборів (далі - НТЗ) з олімпійських видів } \\
\text { спорту з підготовки до всеукраїнських змагань }\end{array}$ & 172 & 141 & -31 \\
\hline $\begin{array}{l}\text { Середні витрати за забезпечення участі (проїзд, добові в дорозі) одного } \\
\text { спортсмена збірних команд області у всеукраїнських змаганнях з олімпій- } \\
\text { ських видів спорту }\end{array}$ & 1700 & 1021 & -679 \\
\hline $\begin{array}{l}\text { Середній розмір заохочення на одного спортсмена/тренера (далі - } \\
\text { СРЗОС/Т) з олімпійських видів спорту (щомісячно) }\end{array}$ & 12333 & 12333 & 0 \\
\hline СРЗОС/Т з олімпійських видів спорту (раз на рік & 103000 & 103000 & 0 \\
\hline \multicolumn{4}{|c|}{$\begin{array}{l}\text { БП: «Утримання центрів фізичної культури і спорту для осіб з інвалідністю і реабілітаційних шкіл } \\
\text { (Мета: Організація фізкультурно-оздоровчої та спортивної діяльності осіб з інвалідністю) }\end{array}$} \\
\hline $\begin{array}{l}\text { Середньомісячна заробітна плата працівника регіональних центрів з фізич- } \\
\text { ної культури і спорту «Інваспорт» }\end{array}$ & 9293 & 9293 & 0 \\
\hline \multicolumn{4}{|c|}{$\begin{array}{l}\text { БП: Проведення НТЗ і змагань та заходів зі спорту осіб з інвалідністю (Мета: Забезпечення підготовки } \\
\text { спортсменів з інвалідністю та фізкультурно-спортивної реабілітації осіб з інвалідністю) }\end{array}$} \\
\hline $\begin{array}{l}\text { СВОЛД НТЗ з видів спорту осіб з інвалідністю з підготовки до регіональ- } \\
\text { них змагань }\end{array}$ & 120 & 158 & 38 \\
\hline $\begin{array}{l}\text { СВОЛД НТЗ з видів спорту осіб з інвалідністю з підготовки до всеукраїн- } \\
\text { ських змагань }\end{array}$ & 120 & 174 & 54 \\
\hline СВОЛД участі у регіональних змаганнях з видів спорту осіб з інвалідністю & 130 & 168 & 38 \\
\hline $\begin{array}{l}\text { Середні витрати на забезпечення участі (проїзд, добові в дорозі) одного } \\
\text { спортсмена збірних команд області у всеукраїнських змаганнях з о видів } \\
\text { спорту осіб з інвалідністю }\end{array}$ & 485 & 493 & 8 \\
\hline
\end{tabular}

Джерело: побудовано за [8].

Загалом у 2019 році, за даними Рахункової палати України, ГРБК не виконували терміни розробки та затвердження паспортів бюджетних програм, визначені в законодавстві [17]. Із року в рік ситуація навіть погіршується, адже якщо у 2018 році своєчасно не було затверджено 32 \% паспортів бюджетних програм, то в 2019 році - 66 \%. [3]. Причини полягають не лише в низькій виконавській дисципліні, а й у тривалих термінах погодження проєктів органами виконавчої влади, що потребує законодавчого урегулювання.

Слід зазначити, що в різних країнах світу на практиці використовуються різні методи оцінки ефективності цільових (або бюджетних) програм: метод аналізу витрат і вигід, метод аналізу витрат і результативності, метод урахування показників майбутніх періодів, метод сукупних ефектів від реалізації програм, метод інтегральних оцінок та інші, які доцільно апробувати у вітчизняній бюджетній практиці. В Україні для місцевих бюджетів розроблена «Методика здійснення порівняльного аналізу ефективності бюджетних програм ГРБК індексно-бальним методом» [12]. Метою такого аналізу є визначення ефективності подібних (аналогічних) бюджетних програм, що виконуються на рівні декількох регіонів. 
Відповідно до Методичних рекомендацій Міністерства фінансів України [15] оцінка економічної ЕБП здійснюється шляхом зіставлення ії відповідності пріоритетам соціально-економічного розвитку країни; планам діяльності ГРБК на поточний та середньостроковий періоди; нормативно-правовим актам; аналізу мети програми та завдань; результативних показників; звітів про виконання за попередні бюджетні періоди тощо. Критеріями оцінки ЕПП за напрямами використання бюджетних коштів $є$ визначення розбіжності між фактичними та плановими результативними показниками. Такий підхід застосовано для оцінки ЕБП за 2019 р., які фінансуються з державного бюджету, де головним розпорядником виступає Міністерство соціальної політики України (табл. 3).

Таблиця 3

Оиінка ефективності окремих бюджетних програм за 2019 рік

за напрямами використання бюджетних коштів, млн грн

\begin{tabular}{|c|c|c|c|c|c|}
\hline \multirow{2}{*}{$\begin{array}{c}\text { КПКВК } \\
\text { ДБ }\end{array}$} & \multirow{2}{*}{ Найменування бюджетної програми } & \multirow{2}{*}{ План } & \multirow{2}{*}{ Факт } & \multicolumn{2}{|c|}{ Відхилення } \\
\hline & & & & млн грн & $\%$ \\
\hline 2501480 & $\begin{array}{l}\text { Надання щомісячної адресної допомоги внутрішньо пе- } \\
\text { реміщеним особам для покриття витрат на проживання, } \\
\text { у тому числі на оплату житлово-комунальних послуг }\end{array}$ & 3011,14 & 2991,26 & $-19,88$ & 0,7 \\
\hline 2501570 & $\begin{array}{l}\text { Виплата матеріальної допомоги військовослужбовцям, } \\
\text { звільненим із військової строкової служби }\end{array}$ & 82,31 & 62,40 & $-19,91$ & 24,2 \\
\hline 2501590 & $\begin{array}{l}\text { Компенсація роботодавцю частини фактичних витрат, } \\
\text { пов'язаних зі сплатою єдиного внеску на загальноо- } \\
\text { бов'язкове державне соціальне страхування }\end{array}$ & 0,80 & 0,63 & $-0,17$ & 21,3 \\
\hline 2501630 & $\begin{array}{l}\text { Модернізація системи соціальної підтримки населення } \\
\text { України }\end{array}$ & 559,98 & 196,47 & $-363,52$ & 64,9 \\
\hline 2507100 & Реабілітація дітей з інвалідністю & 80,01 & 76,62 & $-3,39$ & 4,2 \\
\hline 2501120 & $\begin{array}{l}\text { Розселення та облаштування кримських татар та осіб } \\
\text { інших національностей, які були депортовані з території } \\
\text { України }\end{array}$ & 49982,8 & 46187,7 & $-3,80$ & 0,02 \\
\hline 2501160 & Довічні державні стипендії & 4,22 & 4,19 & $-0,04$ & 0,95 \\
\hline 2501180 & $\begin{array}{l}\text { Виплата соціальної стипендії студентам (курсантам) } \\
\text { вищих навчальних закладів }\end{array}$ & 680,52 & 680,51 & $-0,006$ & 0,0 \\
\hline 2501200 & $\begin{array}{l}\text { Соціальний захист громадян, які постраждали внаслідок } \\
\text { Чорнобильської катастрофи }\end{array}$ & 2335,42 & 2333,38 & $-2,05$ & 0,09 \\
\hline 2501230 & $\begin{array}{l}\text { Виплата пільг і житлових субсидій громадянам на опла- } \\
\text { ту житлово-комунальних послуг у грошовій формі }\end{array}$ & 25293,1 & 23266,8 & $-2026,3$ & 8,0 \\
\hline 2501450 & $\begin{array}{l}\text { Оздоровлення і відпочинок дітей, які потребують особ- } \\
\text { ливої уваги та підтримки, в дитячих оздоровчих таборах } \\
\text { МДЦ „Артек” і ДЦ „Молода Гвардія” }\end{array}$ & 223,32 & 220,43 & $-2,89$ & 1,3 \\
\hline 2501130 & $\begin{array}{l}\text { Заходи із соціального захисту дітей, сімей, жінок та ін- } \\
\text { ших найбільш вразливих категорій населення }\end{array}$ & 41,08 & 36,45 & $-4,63$ & 11,3 \\
\hline
\end{tabular}

Джерело: складено та розраховано за даними [9].

Відповідно до КПКВК ДБ 2501480 у 2019 році 164799 сімей отримали адресну допомогу, середньомісячний розмір адресної допомоги становив 1512,6 грн на одну сім'ю. Ефективність виконання цієї бюджетної програми доволі висока, що відображено у звіті про їі виконання.

У межах видатків, передбачених за бюджетною програмою КПКВК 2501570, здійснено виплату матеріальної допомоги військовослужбовцям, звільненим із військової строкової служби, які звернулися за зазначеною виплатою до органів соціального захисту населення. Значне відхилення від запланованого показника фінансування пов'язане із завищеною прогнозною кількістю військовослужбовців, звільнених із військової строкової служби. Недостовірність прогнозних розрахунків призвела до зниження ефективності бюджетної програми. 
ФІНАНСОВІ РЕСУРСИ: ПРОБЛЕМИ ФОРМУВАННЯ ТА ВИКОРИСТАННЯ

Ефективність програми за КПКВК 2501630 є найнижчою серед усіх програм внаслідок відтермінування створення Державної соціальної служби, отже - скасування чи зупинку торгів, крім того, несвоєчасне виконання ряду робіт (прикладного програмного забезпечення), а відповідно, і значного іiї недофінансування.

Згідно $з$ паспортом бюджетної програми за КПКВК 2501590 кошти 3 державного бюджету в 2019 році спрямовувались на виплату компенсації роботодавцям п'ятдесяти відсотків фактичних витрат, пов'язаних зі сплатою єдиного внеску на загальнообов'язкове державне соціальне страхування. Компенсація здійснювалась за кожну особу, працевлаштовану на нове робоче місце за умови здійснення протягом дванадцяти календарних місяців 3 дня укладання трудового договору з такою особою щомісячної виплати їй заробітної плати в розмірі не менше ніж три мінімальні заробітні плати. Ця програма сприяє створенню нових робочих місць та працевлаштуванню працівників шляхом укладення трудових договорів. Відхилення касових видатків за напрямом використання бюджетних коштів від планового показника пояснюється не підтвердженням окремими роботодавцями права на отримання відповідної компенсації.

Бюджетна програма за КПКВК 2507100 є актуальною у зв’язку з тим, що згідно зі статистичними даними кількість дітей з інвалідністю щороку зростає. Так, станом на 01.01.2018 року було 159044 дитини з інвалідністю, а станом на 01.01.2019 їх кількість становила 161594 особи. Передбачені за цією програмою видатки дали можливість у 2019 році здійснити заходи з реабілітації 4388 дітей з інвалідністю.

У межах бюджетної програми за КПКВК 2501120 зниження її ефективності відбулося внаслідок невикористання коштів, несвоєчасного виконання будівельних робіт.

Бюджетна програма КПКВК 2501200 є актуальною, оскільки дає можливість забезпечувати фінансування гарантованих державою компенсаційних виплат, доплат, різних видів допомоги та пільг, які стосуються всіх постраждалих внаслідок Чорнобильської катастрофи громадян відповідно до визначених категорій. Станом на 01.01.2020 їх чисельність становила 1 млн 769 тис. 442 особи.

У 2019 році за бюджетною програмою КПКВК 2501230 використано 23 266,8 тис. грн. Середньомісячна чисельність одержувачів (домогосподарств), яким призначено житлові субсидії, становила 1822,4 тис. од.; при цьому середньомісячний розмір житлової субсидії становив 965,4 грн. Середньомісячна чисельність осіб, яким надано пільги на оплату житлово-комунальних послуг, становила 1782,2 тис. осіб; при цьому середньомісячний розмір пільги на оплату житлово-комунальних послуг - 596,6 грн.

У межах бюджетної програми за КПКВК 2501450 у 2019 році здійснювалися заходи, спрямовані на досягнення мети та завдань, а саме 22700 дітей, які потребують особливої соціальної уваги та підтримки, забезпечено оздоровленням та відпочинком (у МДЦ «Артек» - 11641 дитину, у ДЦ «Молода гвардія» - 11059 дітей), що становить 99,8 \% від запланованої кількості дітей. Слід зазначити, що більшість дітей, які оздоровлюються в дитячих центрах «Артек» та «Молода гвардія», - це соціально вразливі категорії дітей, а саме: діти-сироти, діти, позбавлені батьківського піклування, діти із малозабезпечених і багатодітних сімей та діти, які проживають у населених пунктах, розташованих на лінії зіткнення (71,2 \% від загальної кількості дітей, оздоровлених у цих центpax). Ефективність використання бюджетних коштів за цією бюджетною програмою доволі висока.

Зниження ефективності бюджетної програми за КПКВК 2501130 відбулося внаслідок невиконання робіт зі створення та забезпечення функціонування державної установи "Кол-центр Міністерства соціальної політики України з питань протидії торгівлі людьми, запобігання та протидії домашньому насильству, насильству за ознакою статі та насильству стосовно дітей” та її територіальних відділень. 
На виконання вимог Конвенції про права осіб з інвалідністю (далі - Конвенція) постановою Кабінету Міністрів України від 01.08.2012 № 706 була затверджена Державна цільова програма «Національний план дій щодо реалізації Конвенції про права осіб з інвалідністю на період до 2020 року» (далі - Національний план) [6]. Програма спрямована на заохочення, захист і забезпечення повного й рівного здійснення особами з інвалідністю всіх прав людини, свобод у всіх сферах суспільного життя тощо. Станом на кінець листопада 2020 р. у Національному плані було передбачено 72 заходи, 40 заходів було виконано, 15 - виконано частково, реалізація ще 7 триває і 10 заходів не виконано [4]. Ця програма виконується у складі багатьох бюджетних програм: КПКВК 2301180 «Санаторне лікування хворих на туберкульоз та дітей і підлітків з соматичними захворюваннями», КПКВК 2501090 «Створення і програмно-технічне забезпечення системи інформаційноаналітичної підтримки, інформаційно-методичне забезпечення та виготовлення бланків посвідчень і нагрудних знаків для системи соціального захисту» та інших.

Таким чином, проведений аналіз дає підстави згрупувати причини зниження ефективності бюджетних програм (за критерієм виконання бюджетної програми «за напрямами використання коштів») на суб'єктивні (зумовлені недоліками у прогнозуванні та плануванні) і об’єктивні (зумовлені зовнішніми факторами). Низькі фактичні показники фінансування порівняно із плановими значеннями пов'язані не лише з недофінансуванням бюджетних програм, що має негативні соціальні наслідки, а й 3 дією низки об'єктивних факторів.

Водночас відсутність чіткого визначення виконавців та їх відповідальності за виконання конкретних заходів потребує вдосконалення методики контролю за витрачанням коштів та методики оцінки соціально-економічних ефектів державних цільових програм, які реалізуються за кошти державного бюджету.

Міністерство економічного розвитку і торгівлі України визначило комплекс системних недоліків виконання державних цільових програм у 2015-2018 pp. [20]. Із визначених недоліків основними при плануванні бюджетних програм у 2019-2020 рр., які впливають на ефективність використання бюджетних коштів, більшість залишається актуальними для вирішення. Проте водночас слід виокремити й інші:

- проблеми у визначенні цілей програми (нечіткість формулювання, нереалістичність досягнення, взагалі змішування понять мета і процес);

- недосконалість та необгрунтованість результативних показників щодо їх кількості, зокрема надмірна деталізація;

- включення показників, які не дозволяють оцінити ефективність програми;

- завищення значень окремих показників.

Наслідками недоліків у плануванні бюджетних програм стають постійні уточнення бюджетних призначень, зниження і перерозподіл бюджетних коштів, прийняття неефективних управлінських рішень, що призводить до нераціонального використання робочого часу та непродуктивного використання чи додаткових витрат бюджетних коштів.

Останніми роками в Україні зроблено кроки для запровадження світової практики здійснення оглядів бюджетних витрат, важливим результатом яких є розроблення рекомендацій щодо підвищення якості публічних послуг та забезпечення досягнення цілей бюджетної політики й водночас оптимізація видатків державного бюджету в координатах «економія коштів - зростання видатків». Напрацювання у цій сфері тривають, розширюється коло розпорядників і сфер огляду. Так, якщо в 2018 році за проведення оглядів бюджетних витрат було обрано 5 ГРБК і 5 сфер, у 2019 році - 5 розпорядників та 9 сфер, то в 2020 році їх кількість зросла відповідно до 12 та 15. Треба зазначити, що у 2020 році заплановано охоплення оглядами майже 28 \% видатків за бюджетними про- 
ФІНАНСОВІ РЕСУРСИ: ПРОБЛЕМИ ФОРМУВАННЯ ТА ВИКОРИСТАННЯ

грамами із загальної суми видатків державного бюджету [10]. Комплексна оцінка результативності/ефективності використання бюджетних коштів, як результат оглядів бюджетних витрат за 2019 рік, на сьогодні не оприлюднена, що робить іiі здійснення непрозорим і недоступним громадськості. Впровадження у вітчизняну практику огляду бюджетних видатків не має бути формальним, а має стати дієвим інструментом визначення/коригування цілей бюджетної політики людського розвитку.

Оцінка ефективності реалізації бюджетних програм потребує впровадження нових підходів. Як показав аналіз, існуючі на сьогодні підходи спрямовані переважно на аналіз відхилень фактичних значень від планових, що закріплено нормативно-правовими актами. Основним об'єктом аналізу є бюджетні видатки на реалізацію програм, а відповідно до ключового принципу програмно-цільового методу мають бути результати реалізації програм.

Слушною є пропозиція Ф. Журавки та Н. Овчарової щодо здійснення оцінювання динаміки певних показників, що характеризують рівень розвитку соціальної сфери, з формуванням на основі результатів такого аналізу висновків щодо ефективності програми [7]. До цих показників, на наш погляд, доцільно додати показники, що характеризують розвиток людського капіталу та дозволять зробити висновки щодо ефективності програм у сфері охорони здоров'я, освіти тощо. Важливим $є$ врахування впливу певних негативних/позитивних факторів на показники, виникнення яких не $\epsilon$ наслідком реалізації державних цільових програм для усунення викривлень при оцінці ефективності їх виконання.

Висновки і пропозиції. Головним завданням бюджетної політики $є$ підвищення ефективності використання бюджетних коштів для підвищення якості публічних послуг у сферах, що забезпечують розвиток людини та підтримку іiі життєдіяльності, шляхом удосконалення механізмів управління видатками. Бюджетні програми є дієвим інструментом сучасної бюджетної політики щодо вирішення стратегічних завдань у соціальній та інших сферах, які виникають у результаті дії різноманітних чинників зовнішнього та внутрішнього характеру. У процесі оцінювання бюджетних програм соціального спрямування формуються показники, яких треба досягти та за якими визначаються ефективність реалізації тієї чи іншої програми. У результаті аналізу ефективності бюджетних програм соціального спрямування виявлено недофінансування окремих із них, що свідчить про невідповідність прогнозних обсягів бюджетних коштів при плануванні програм із реальними можливостями їх фінансування, недоліки у плануванні. Згруповано причини зниження ефективності реалізації бюджетних програм на суб'єктивні (зумовлені недоліками у прогнозуванні та плануванні) і об'єктивні (зумовлені зовнішніми факторами).

Реалізація програмно-цільового методу планування та фінансування для забезпечення/стимулювання людського розвитку та підтримки соціально вразливих прошарків населення (насамперед, охорони здоров'я, освіти, соціального захисту) потребує удосконалення. Значну увагу доцільно приділяти формуванню цілей і завдань бюджетних програм у середньостроковому форматі в більш тісному зв'язку з проблемами людського розвитку, для вирішення яких такі програми розробляються. Вітчизняна практика формування програмного бюджету свідчить, що певна частина видатків не відповідає ознакам бюджетної програми, відображає поточне фінансове забезпечення діяльності певних установ.

Важливим на сучасному етапі $є$ повноцінне впровадження практики здійснення оглядів бюджетних витрат, невід'ємною складовою яких є розробка рекомендацій щодо підвищення ефективності видатків для надання якісних публічних послуг та забезпечення досягнення цілей бюджетних програм як інструменту бюджетної політики людського розвитку. 
Оцінка ефективності реалізації бюджетних програм потребує впровадження нових підходів з урахуванням світового досвіду, що $є$ перспективою подальших досліджень.

\section{Список використаних джерел}

1. Бюджетний кодекс України від 08.07.2010 № 2456-VI. URL: http://zakon5.rada.gov.ua/ laws/show/en/2456-17.

2. Бюджетна складова реалізації домінантних напрямів суспільного розвитку : монографія / за наук. ред. Л. В. Лисяк. Дніпропетровськ : ДДФА, 2015. 396 с.

3. Видатки Державного бюджету України в 2019-2020 роках. Програмна класифікація. URL: openbudget.gov.ua/annual-budget/expreses?class=program.

4. Висновки про результати річного звіту про виконання Закону України «Про державний бюджет України за 2019 рік» / Рахункова палата України. 2020. URL: rp.gov.ua/uploadfiles/Activity/Collegium/2020/9-1_2020/Vysn_9-1_2020/Vysn_9_1_2020.pdf.

5. Відбулося засідання Ради у справах осіб з інвалідністю. URL: https://www.kmu.gov.ua/ news/vidbulosya-zasidannya-radi-u-spravah-osib-z-invalidnistyu.

6. Державна цільова програма «Національний план дій щодо реалізації Конвенції про права осіб з інвалідністю" на період до 2020 року». URL: https://zakon.rada.gov.ua/laws/show/706-2012$\% \mathrm{D} 0 \% \mathrm{BF} \#$ Text.

7. Журавка Ф. О., Овчарова Н. В. Оцінка ефективності реалізації державних цільових програм у соціальній сфері. Бізнес Інформ. 2014. № 6. С. 202-206.

8. Звіти про виконання паспортів бюджетних програм за 2019 рік / Дніпропетровська обласна державна адміністрація. 2020. URL: adm.dp.gov.ua/file-storage/sport-2019-zvit-pasportiv.

9. Інформація про мету, завдання та результативні показники бюджетних програм на 2019 рік. URL: https://mon.gov.ua/storage/app/media/budzhet/2020/09/220.pdf.

10. Касперович Ю. В., Дешко А. Л. Про удосконалення організації проведення оглядів витрат державного бюджету в сучасних умовах. URL: niss.gov.ua/sites/default/files/2020-08/vytratyderzh-budget.pdf.

11. Корнієнко Н. М. Оцінка і моніторинг ефективності бюджетних програм. Економічний чаconuc-XXI. 2013. № 5-6 (2). С. 31-33.

12. Методика здійснення порівняльного аналізу ефективності бюджетних програм : Лист Міністерства фінансів від 19.09.2013 № 31-05110-14-5/27486. URL: ibser.org.ua.

13. Оцінка ефективності бюджетних програм за 2019 рік. URL: https://www.msp.gov.ua/ timeline/Derzhbyudzhet.html.

14. Про схвалення Концепції застосування програмно-цільового методу в бюджетному процесі : Розпорядження Кабінету Міністрів України від 14 вересня 2002 р. № 538-p. URL: http://search.ligazakon.ua/1_doc2.nsf/link1/KR020538.html.

15. Про затвердження Методичних рекомендацій щодо здійснення оцінки ефективності бюджетних програм : Наказ Міністерства фінансів України від 17.05.2011 року № 608. URL: http:/www.minfin.gov.ua/control/uk/publish/article/main?art_id=293133\&cat_id=50097\&search_prog $\mathrm{ram}=\% \mathrm{ED} \% \mathrm{E} 0 \% \mathrm{EA} \% \mathrm{E} 7+608 \&$ searchDocarch $=1 \&$ searchPublishing $=1$.

16. Про деякі питання запровадження програмно-цільового методу складання та виконання місцевих бюджетів: Наказ Міністерства фінансів України від 26.08.2014 № 836. URL: https://goo.gl/wZUscq.

17. Перелік регіональних цільових програм, які діють у 2019 році (по напрямам). URL: https://adm.dp.gov.ua/storage/app/media/uploaded-

files/perelik_regionalnih_cilovih_program_stanom_na_1_01_2019.pdf.

18. Реалізація норм Конвенції про права осіб 3 інвалідністю. URL: https://www.msp.gov.ua/timeline/Realizaciya-norm-Konvencii-pro-prava-osib-z-invalidnistyu.html.

19. Савченко В. Ф. Регулювання соціального розвитку в Україні через інвестиційноінноваційні важелі та інструменти. Проблеми і перспективи економіки та управління. 2019. № 2 (18). C. 163-173. URL: http://ppeu.stu.cn.ua/article/view/184234/183985.

20. Стан виконання державних цільових програм у 2015-2018 pp. URL: http://www.me.gov.ua/Documents/List?lang=ukUA\&tag=DerzhavniTsiloviProgrami. 
ФІНАНСОВІ РЕСУРСИ: ПРОБЛЕМИ ФОРМУВАННЯ ТА ВИКОРИСТАННЯ

21. Тимченко О. М. Теоретичні засади та прагматика програмно-цільового методу фінансування вищої освіти в Україні. Фінанси Украӥни. 2018. № 11. С. 7-20.

22. Чугунов I. Я. Бюджетна політика в умовах економічних перетворень. Матеріали I Всеукраӥнської конферениї «БОГОЛІБСБКІ ЧИТАННЯ» (м. Переяслав 18 вересня 2020 р.). Перяслав : ДВНЗ «Переяслав-Хмельницький державний педагогічний університет імені Григорія Сковороди», 2020. С. 8-11.

23. Lysiak L., Kachula S., Hrabchuk O., Filipova M., Kushnir A. Assessment of financial sustainability of the local budgets: case of Ukraine. Public and Municipal Finance. 2020. Vol. 9, Issue 1. Pp. 48-59. DOI: http://dx.doi.org/10.21511/pmf.09(1).2020.05.

24. Senyshyn O., Chopko N., Zhuk I. Integral estimate of the effectiveness of performance of indices of state target programs for the protection of the natural environment in Ukraine. Baltic Journal of Economic Studies. 2017.№ 3(5). Pp. 391-399. DOI: https://doi.org/10.30525/22560742/2017-3-5-391-399.

25. Shkarlet, S., Dolozina, I., \& Dubyna, M. (2019). Budgetary revenue breakdown at the local level of public administration in federal countries. Baltic Journal of Economic Studies. 2019. Vol. 5, No. 3. Pp. 218-224.

\section{References}

1. Biudzhetnyi kodeks Ukrainy [Budget Code of Ukraine]. № 2456-VI (July 8, 2010). http://zakon5.rada.gov.ua/laws/show/en/2456-17.

2. Lysiak, L. V. (Ed.) (2015). Biudzhetna skladova realizatsii dominantnykh napriamiv suspilnoho rozvytku [Budget component of the implementation of dominant areas of social development]. DDFA.

3. Vydatky Derzhavnoho biudzhetu Ukrainy v 2019-2020 rokakh. Prohramna klasyfikatsiia [Expenditures of the State Budget of Ukraine in 2019-2020. Software classification]. openbudget.gov.ua/annual-budget/expreses?class=program.

4. Rakhunkova palata Ukrainy [Accounting Chamber of Ukraine ] (2020). Vysnovky pro rezultaty richnoho zvitu pro vykonannia Zakonu Ukrainy «Pro derzhavnyi biud;et Ukrainy za 2019 rik» [Conclusions on the results of the annual report on the implementation of the Law of Ukraine "On the State Budget of Ukraine for 2019»]. rp.gov.ua/upload-files/Activity/Collegium/2020/91_2020/Vysn_9-1_2020/Vysn_9_1_2020.pdf.

5.Vidbulosia zasidannia Rady u spravakh osib z invalidnistiu [A meeting of the Council for Persons with Disabilities was held]. https://www.kmu.gov.ua/news/vidbulosya-zasidannya-radi-uspravah-osib-z-invalidnistyu.

6. Derzhavna tsilova prohrama «Natsionalnyi plan dii shchodo realizatsii Konventsii pro prava osib z invalidnistiu" na period do 2020 roku [State target program «National Action Plan for the Implementation of the Convention on the Rights of Persons with Disabilities» until 2020]. https://zakon.rada.gov.ua/laws/show/706-2012-\%D0\%BF\#Text.

7. Zhuravka, F. O., \& Ovcharova, N. V. (2014). Otsinka efektyvnosti realizatsii derzhavnykh tsilovykh prohram u sotsialnii sferi. Biznes Inform - Business Inform, (6), pp. 202-206.

8. Dnipropetrovska oblasna derzhavna administratsiia [Dnipropetrovsk Regional State Administration ]. (2020). Zvity pro vykonannia pasportiv biudzhetnykh prohram za 2019 rik [Reports on the implementation of passports of budget programs for 2019. Dnipropetrovsk Regional State Administration, 2020]. adm.dp.gov.ua/file-storage/sport-2019-zvit-pasportiv.

9. Informatsiia pro metu, zavdannia ta rezultatyvni pokaznyky biudzhetnykh prohram na 2019 rik [Information on the purpose, objectives and performance indicators of budget programs for 2019]. https://mon.gov.ua/storage/app/media/budzhet/2020/09/220.pdf.

10. Kasperovych, Yu. V., \& Deshko, A. L. (2020). Pro udoskonalennia orhanizatsii provedennia ohliadiv vytrat derzhavnoho biudzhetu $v$ suchasnykh umovakh [About improvement of the organization of carrying out of reviews of expenses of the state budget in modern conditions]. niss.gov.ua/sites/default/files/2020-08/vytraty-derzh-budget.pdf.

11. Korniienko, N. M. (2013). Otsinka i monitorynh efektyvnosti biudzhetnykh prohram [Evaluation and monitoring of the effectiveness of budget programs]. Ekonomichnyi chasopys-XXIEconomic annals-XXI, (5-6 (2)), pp. 31-33. 
12. Metodyka zdiisnennia porivnialnoho analizu efektyvnosti biudzhetnykh prohram [Methods of comparative analysis of the effectiveness of budget programs], Letter from the Ministry of Finance № 31-05110-14-5/27486 (19.09.2013). ibser.org.ua.

13. Otsinka efektyvnosti biudzhetnykh prohram za 2019 rik [Evaluation of the effectiveness of budget programs for 2019]. https://www.msp.gov.ua/timeline/Derzhbyudzhet.html.

14. Pro skhvalennia Kontseptsii zastosuvannia prohramno-tsilovoho metodu $\mathrm{v}$ biudzhetnomu protsesi [On approval of the Concept of application of the program-target method in the budget process], Order of the Cabinet of Ministers of Ukraine № 538-r (14 September, 2002). http://search.ligazakon.ua/1_doc2.nsf/link1/KR020538.html

15. Pro zavtverdzhennia Metodychnykh rekomendatsii shchodo zdiisnennia otsinky efektyvnosti biudzhetnykh prohram [On approval of Methodical recommendations for evaluating the effectiveness of budget programs], Order of the Ministry of Finance of Ukraine № 608 (May 17, 2011). http:/www.minfin.gov.ua/control/uk/publish/article/main?art_id=293133\&cat_id=50097\&search_prog $\mathrm{ram}=\% \mathrm{ED} \% \mathrm{E} 0 \% \mathrm{EA} \% \mathrm{E} 7+608 \&$ searchDocarch $=1 \&$ searchPublishing $=1$.

16. Pro deiaki pytannia zaprovadzhennia prohramno-tsilovoho metodu skladannia ta vykonannnia mistsevykh biudzhetiv [On some issues of introduction of the program-target method of drawing up and execution of local budgets], Order of the Ministry of Finance of Ukraine № 836 (July 26, 2014). https://goo.gl/wZUscq.

17. Perelik rehionalnykh tsilovykh prohram, yaki diiut u 2019 rotsi [List of regional target programs operating in 2019]. https://adm.dp.gov.ua/storage/app/media/uploadedfiles/perelik_regionalnih_cilovih_program_stanom_na_1_01_2019.pdf.

18. Realizatsiia norm Konventsii pro prava osib $\mathrm{z}$ invalidnistiu [Implementation of the norms of the Convention on the Rights of Persons with Disabilities]. https://www.msp.gov.ua/ timeline/Realizaciya-norm-Konvencii-pro-prava-osib-z-invalidnistyu.html.

19. Savchenko, V. F. (2019). Rehuliuvannia sotsialnoho rozvytku v Ukraini cherez investytsiinoinnovatsiini vazheli ta instrumenty [Regulation of social development in Ukraine through investment and innovation levers and tools]. Problemy i perspektyvy ekonomiky ta upravlinnia-Problems and prospects of economics and management, (2(18)), pp. 163-173. http://ppeu.stu.cn.ua/article/view/ $184234 / 183985$.

20. Stan vykonannia derzhavnykh tsilovykh prohram u 2015-2018 rr. [Status of implementation of state target programs in 2015-2018]. http://www.me.gov.ua/Documents/List?lang= ukUA\&tag=DerzhavniTsiloviProgrami.

21. Tymchenko, O. M. (2018). Teoretychni zasady ta prahmatyka prohramno-tsilovoho metodu finansuvannia vyshchoi osvity $\mathrm{v}$ Ukraini [Theoretical principles and pragmatics of the programtargeted method of financing higher education in Ukraine]. Finansy Ukrainy - Finance of Ukraine, (11), pp. 7-20.

22. Chuhunov, I. Ya. (2020). Biudzhetna polityka v umovakh ekonomichnykh peretvoren [Fiscal policy in the context of economic transformation]. Materialy I Vseukrainskoi konferentsii "BOHOLIBSKI CHYTANNIA» - Proceedings of the I All-Ukrainian Conference "BOGOLIBSKY READINGS» (Pereiaslav, September 18, 2020). DVNZ «Pereiaslav-Khmelnytskyi derzhavnyi pedahohichnyi universytet imeni Hryhoriia Skovorody».

23. Lysiak, L., Kachula, S., Hrabchuk, O., Filipova, M. \& Kushnir, A. (2020). Assessment of financial sustainability of the local budgets: case of Ukraine. Public and Municipal Finance, 9(1), pp. 48-59. DOI: http://dx.doi.org/10.21511/pmf.09 (1).2020.05.

24. Senyshyn, O., Chopko, N., \& Zhuk, I. (2017). Integral estimate of the effectiveness of performance of indices of state target programs for the protection of the natural environment in Ukraine. Baltic Journal of Economic Studies, (3(5)), pp. 391-399. DOI: https://doi.org/10.30525/22560742/2017-3-5-391-399.

25. Shkarlet, S., Dolozina, I., \& Dubyna, M. (2019). Budgetary revenue breakdown at the local level of public administration in federal countries. Baltic Journal of Economic Studies, 5(3), pp. 218-224. 
ФІНАНСОВІ РЕСУРСИ: ПРОБЛЕМИ ФОРМУВАННЯ ТА ВИКОРИСТАННЯ

Козьменко Сергій Миколайович - доктор економічних наук, професор, професор кафедри державних, місцевих та корпоративних фінансів, Університет митної справи та фінансів (вул. Володимира Вернадського, 2/4, м. Дніпро, 49000, Україна).

Козьменко Сергей Николаевич - доктор экономических наук, профессор, профессор кафедры государственных, местных и корпоративных финансов, Университет таможенного дела и финансов (ул. Владимира Вернадского, 2/4, г. Днепр, 49000, Украина).

Kozmenko Serhiy - Doctor of Economics, Professor, Professor of Department of State, Local and Corporative Finance, University of Customs and Finance (2/4 Volodymyr Vernadsky Str., 49000 Dnipro, Ukraine)

E-mail: kozmenko.uabs@gmail.com

ORCID: http://orcid.org/0000-0001-7710-484

Качула Світлана Валентинівна - доктор економічних наук, доцент, професор кафедри фінансів, банківської справи та страхування, Дніпровський державний аграрно-економічний університет (вул. Сергія Сфремова, 25, м. Дніпро, 49000, Україна).

Качула Светлана Валентиновна - доктор экономических наук, доцент, профессор кафедры финансов, банковского дела и страхования, Днепровский государственный аграрно-экономический университет (ул. Сергея Ефремова, 25, г. Днепр, 49000, Украина).

Kachula Svitlana - Doctor of Economics, Associate Professor, Professor of the Department of Finance, Banking and Insurance, Dnipro State Agrarian and Economics University (25 Sergei Efremov Str., 49000 Dnipro, Ukraine).

E-mail: s.kachula@ukr.net

ORCID: https://orcid.org/0000-0003-2540-862X 